\title{
Assessing Energy and Environmental Efficiency of the Spanish Agri-Food System Using the LCA/DEA Methodology
}

\author{
Jara Laso ${ }^{1, *}$, Daniel Hoehn ${ }^{1}$, María Margallo ${ }^{1}$, Isabel García-Herrero ${ }^{1}$, Laura Batlle-Bayer ${ }^{2}$, \\ Alba Bala ${ }^{2}$, Pere Fullana-i-Palmer ${ }^{2}$, Ian Vázquez-Rowe ${ }^{3}$, Angel Irabien ${ }^{1}$ and Rubén Aldaco ${ }^{1}$ \\ 1 Department of Chemical and Biomolecular Engineering, University of Cantabria, Avda. de los Castros s/n, \\ 39005 Santander, Spain; daniel.hoehn@unican.es (D.H.); margallom@unican.es (M.M.); \\ isabel.garciaherrero@unican.es (I.G.-H.); irabiena@unican.es (A.I.); aldacor@unican.es (R.A.) \\ 2 UNESCO Chair in Life Cycle and Climate Change ESCI-UPF, Universitat Pompeu Fabra, Pg. Pujades 1, \\ 08003 Barcelona, Spain; laura.batlle@esci.upf.edu (L.B.-B.); alba.bala@esci.upf.edu (A.B.); \\ pere.fullana@esci.upf.edu (P.F.-i-P.) \\ 3 Peruvian LCA Network, Department of Engineering, Pontificia Universidad Católica del Perú, Av. \\ Universitaria 1801, San Miguel, Lima 15088, Peru; ian.vazquez@pucp.pe \\ * Correspondence: jara.laso@unican.es; Tel.: +34-942-846-531
}

Received: 31 October 2018; Accepted: 30 November 2018; Published: 4 December 2018

\begin{abstract}
Feeding the world's population sustainably is a major challenge of our society, and was stated as one of the key priorities for development cooperation by the European Union (EU) policy framework on food security. However, with the current trend of natural resource exploitation, food systems consume around 30\% of final energy use, generating up to $30 \%$ of greenhouse gas (GHG) emissions. Given the expected increase of global population (nine billion people by 2050) and the amount of food losses and waste generated (one-third of global food production), improving the efficiency of food systems along the supply chain is essential to ensure food security. This study combines life-cycle assessment (LCA) and data envelopment analysis (DEA) to assess the efficiency of Spanish agri-food system and to propose improvement actions in order to reduce energy usage and GHG emissions. An average energy saving of approximately $70 \%$ is estimated for the Spanish agri-food system in order to be efficient. This study highlights the importance of the DEA method as a tool for energy optimization, identifying efficient and inefficient food systems. This approach could be adopted by administrations, policy-makers, and producers as a helpful instrument to support decision-making and improve the sustainability of agri-food systems.
\end{abstract}

Keywords: data envelopment analysis; energy efficiency; food loss and waste; life-cycle assessment

\section{Introduction}

The food industry is one of the major manufacturing sectors, representing $15 \%$ of the sales in the European Union and more than 1,120,000 million euros [1]. However, the rapid growth of global population and its corresponding consequences, such as the increasing demand of food production, caused an intensive use of energy resources [2]. In this sense, a considerable use of energy, estimated at $30 \%$ of the total energy consumption, is attributed to agri-food systems [1]. Given the strong dependency on fossil fuels of our current energy system, such energy consumption is responsible for $20-30 \%$ of total anthropogenic greenhouse gases (GHG) [3]. This fact results in the depletion of fossil resources and GHG emissions being of major concern. Energy is required at every stage in food production, including the cultivation and harvesting of crops, animal husbandry, transportation and distribution, and food processing for consumption, with the agricultural stage as the most critical [4]. 
This causes a low efficiency for food systems, with around $10 \mathrm{kcal}$ of fossil fuel energy to produce $1 \mathrm{kcal}$ of food [1]. Some foods are very efficient in their use of resources to produce a nutritious meal, such as fruits and vegetables, while others are very inefficient, such as animal-based products. In general, animal foods require eight times more energy per calorie than plant-based commodities [5].

Concerns regarding inefficiency are wider when food losses and waste (FLW) are taken into account. According to the Organization for Economic Co-operation and Development (OECD) [6], more than one-third of the food produced worldwide is lost along the supply chain, involving around $38 \%$ of the energy consumed in its production. In fact, FLW was identified as a major global concern putting at risk environmental, economic, and health security [7]. This food produced is, therefore, lost or wasted from initial agricultural production down to final household consumption. Since the embodied amount of energy builds up along the chain, the later the waste occurs, the higher the energy waste and the related GHG emissions will be. In addition, due to the expected global population increase, a $60 \%$ rise in food production was forecasted for the year 2050, entailing a $50 \%$ rise in global energy consumption [8]. Therefore, the efficient use of energy is a necessary step toward reducing environmental hazards, preventing destruction of natural resources, and ensuring food sustainability [9].

With the aim of attaining sustainability, many analytical tools are applied individually or combined to determine an appropriate productive performance. Life-cycle assessment (LCA) is a powerful tool that assesses the environmental impacts of products, processes, and services; it gained in acceptance since it first appeared in the 1990s and is today well established [10]. Many authors used LCA to assess the energy efficiency of their processes. For instance, Marique and Rossi [11], Ingrao et al. [12], and Berg and Fuglseth [13] applied LCA to energy uses in the building sector, while $\mathrm{Li}$ and Feng [14] used it to improve the energy recovery from sewage sludge comparing different pathways. Sundaram et al. [15] assessed the energy efficiency of the production of gasoline from biogas and pyrolysis oil using an LCA approach. Regarding the agri-food sector, Carrasquer et al. [16] created a new indicator to estimate the water and energy efficiency in agro-industries based on life-cycle thinking methodologies. Skunca et al. [17] performed the LCA of the chicken meat chain to estimate the cumulative energy demand (CED), while Pires-Gaspar et al. [18] carried out an energy-LCA of Portuguese peach production using energy efficiency indicators.

On the other hand, additional methods to compute which resource/technology combinations provide the highest amounts of net energy to society are reported as energy return ratios (ERRs) [19]. The most well-known indicator is the energy return on investment (EROI). In fact, its use is widespread within the energy sector to determine the energy that is returned from an energy-collecting process as compared to the embodied energy to provide this energy [20]. However, in recent years, some authors highlighted the benefits of calculating EROI ratios to monitor energy return in food systems [21]. For instance, Laso et al. [22,23], Vázquez-Rowe et al. [20], Tyedmers [24], and Ramos et al. [25] applied the EROI ratio to fishery systems. Cancino-Espinoza et al. [26] computed the EROI of organic quinoa, and Pérez Neira et al. [27] estimated the EROI of tomato production.

In contrast to traditional EERs, the use of the data envelopment analysis (DEA) enables the identification of energy-saving targets for energy-inefficient processes [28]. DEA is a non-parametric multi-input/output linear approach for the calculation of the relative efficiency of a set of comparable decision-making units (DMUs) [29]. In recent years, the application of DEA increased in the fields of environmental and energy. For instance, DEA was applied in the building sector [30-32], the power industry [33,34], the food production sector [1,9,35], and for agricultural production [36-38]. Moreover, it was also used with economic and social variables [3]. The combination of LCA and DEA for the identification and quantification of potential environmental consequences of operational inefficiencies experienced a pronounced increase, and enriched the interpretation of results $[39,40]$. Several previous studies used the joint LCA/DEA method in different agricultural production systems: fisheries [41,42], grapes for winemaking [39], wheat [43], rice [44], and dairy farms [45,46]. 
In this contribution, a hybrid approach which combines EROI, LCA, and DEA is proposed to assess the energy and environmental efficiency of agri-food systems. The capabilities of this combined approach are illustrated through its application to the Spanish agri-food system in order to explore the operational inefficiencies and improvement actions.

\section{Materials and Methods}

Figure 1 depicts the methodology described in this analysis, which attempted to assess the energy and environmental efficiency of Spanish agri-food system using a life-cycle approach. Firstly, an LCA was conducted to estimate the primary energy demand (PED) and related global warming potential (GWP). Secondly, the EROI was estimated to describe the energy efficiency of food categories under study. Finally, DEA was synergistically combined with LCA results to assess the efficiency of the system.

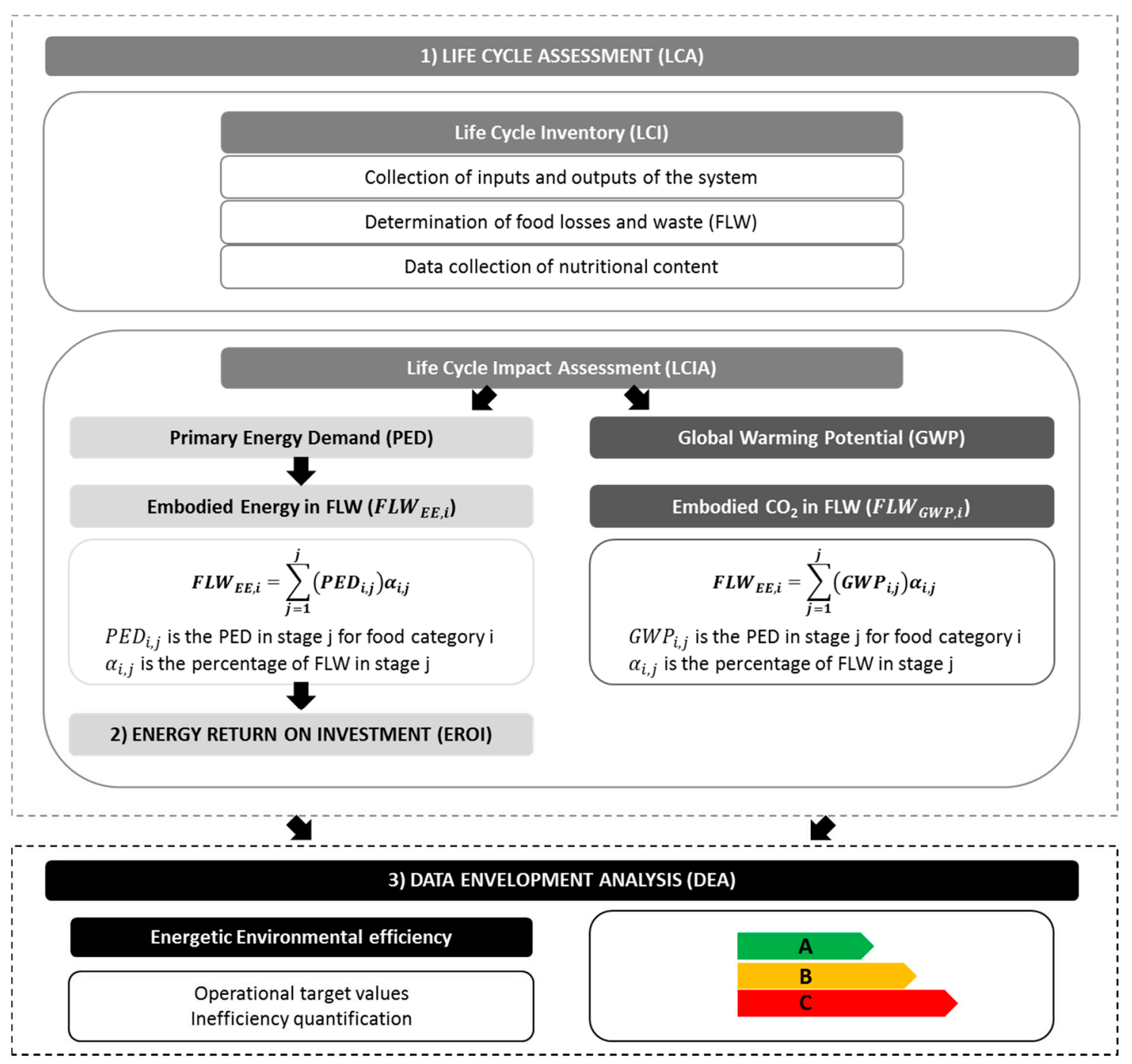

Figure 1. Schematic representation of the methodology applied.

\subsection{Life-Cycle Assessment (LCA)}

LCA is a powerful tool for performing the potential environmental assessment of impacts and resource consumption throughout a product's life cycle [47]. In this regard, LCA became one of the most relevant methodologies to help organizations perform their activities in the most environmental friendly way along the whole value chain. 
In the current study, LCA was conducted following the recommendations of International Organization for Standardization (ISO) 14040 and 14044 international standards [48,49], and was divided into four stages.

\section{(i). Goal and Scope Definition}

This stage consisted of a detailed definition of the intended application of the study in terms of the system boundaries and functional unit (FU) [50,51]. Moreover, allocation procedures, cut-off rules, and assumptions were also defined in this step.

\section{(ii). Life-Cycle Inventory (LCI)}

In this stage, all relevant energy, water, and material consumptions, and emissions, effluents, and residues of the process in a specific temporality and geography were collected [52]. Therefore, in this stage, it was necessary to determine the FLW flows. Moreover, in this study, the LCI also collected data about the nutritional content of the different food categories.

\section{(iii). Life-Cycle Impact Assessment (LCIA)}

The LCIA step transformed the inputs and outputs of the LCI into environmental impact over all of the stages involved in the supply chain. In this study, the impact assessment method selected followed the International Reference Life Cycle Data Product Environmental Footprint (ILCD/PEF) recommendations v1.09 for determining the global warming potential (GWP). The consumption of primary energy resources (net calorific value, PED) was determined according to PE International's [53] life-cycle inventory. Once the PED and GWP embodied along the agri-food supply chain (FSC) were determined, the embodied energy and GHG emissions in FLW could be determined using FLW rates from Gustvasson et al. [54], as indicated Equations (1) and (2).

$$
\begin{gathered}
\operatorname{FLW}_{\mathrm{EE}, \mathrm{i}}=\sum_{\mathrm{j}=1}^{\mathrm{j}}\left(\operatorname{PED}_{\mathrm{i}, \mathrm{j}}\right) \alpha_{\mathrm{i}, \mathrm{j}}, \\
\mathrm{FLW}_{\mathrm{GWP}, \mathrm{i}}=\sum_{\mathrm{j}=1}^{\mathrm{j}}\left(\mathrm{GWP}_{\mathrm{i}, \mathrm{j}}\right) \alpha_{\mathrm{i}, \mathrm{j}}
\end{gathered}
$$

where PED $D_{i, j}$ is the PED in stage $j$ for food category $i, \alpha_{i, j}$ is the percentage of FLW in stage $j$ for food category $i$, and $G_{W P}, j$ is the GWP of stage $j$ for food category $i$ (see the example in Section $S 4$ of the Supplementary Materials).

\section{(iv). Interpretation of the Results}

\subsection{Energy Return on Investment (EROI)}

The concept of EROI is part of the field of net energy analysis (NEA), and is one way of measuring and comparing the net energy availability from different energy sources and processes. In general, EROI can be defined as "the ratio between the energy returned from an energy-gathering activity compared to the embodied energy in that process" [55]. Although this concept was used initially to develop an energy-focused approach to the economy [56], the concept was adapted to calculate ratios between food energy output and food production energy inputs. In this sense, the most commonly used EROI perspective is the human-edible food energy return on industrially energy investment, as indicated in Equation (3). This provides an anthropocentric perspective on the non-renewable resource efficiencies of competing food production technologies [5]. Therefore, the higher the EROI of a food system is, the more "valuable" it is in terms of producing (nutritionally) useful energy output.

$$
\text { EROI }=\frac{\sum_{j=1}^{j} \operatorname{Food}_{i, j} \times \mathrm{NC}_{i, j}}{\sum_{j=1}^{j} \operatorname{PED}_{i, j}},
$$


where Food $_{i, j}$ represents the amount of the food category $i$ available in stage $j$ after withdrawing the $\mathrm{FLW}, \mathrm{NC}_{\mathrm{i}, \mathrm{j}}$ is the nutritional content of food category $\mathrm{i}$ in supply chain $\mathrm{j}$ expressed in $\mathrm{kcal}$, and $\mathrm{PED}_{\mathrm{i}, \mathrm{j}}$ is the PED in stage $\mathrm{j}$ for food category i calculated using LCA.

\subsection{Data Envelopment Analysis (DEA)}

DEA is a non-parametric method widely used to compare the inputs and outputs of a set of homogenous DMUs. This method focuses on evaluating the performance of DMUs based on the evaluation of relative efficiency of comparable DMUs by estimating an empirical efficient boundary [9].

Charnes, Cooper, and Rhodes (CCR) introduced the DEA method for the first time. The original CCR model was applicable to the assumption of constant returns to scale (CRS) [57]. In this sense, the $\mathrm{CCR}$ model considers that the efficiency frontier is a straight line intersecting the point of origin and the best performer(s), as shown in Figure 2a. The best performer is determined by the highest ratio of output to input; thus, as $\mathrm{DMU}_{2}$ has this condition, it is considered as the reference DMU for all other units [38]. The remaining four DMUs in Figure 2a are inefficient since they use more amounts of input than DMU $\mathrm{P}_{2}$ to produce one unit of output.

Banker et al. [58] modified the CCR model by introducing the so-called "convexity constraint", which changed the efficiency frontier from being a straight line to a convex hull (see Figure 2b). The new model, referred to as BCC, was built based on variable returns to scale (VRS). This model presents two advantages as compared to the CCR model: (i) more units can potentially be considered efficient, and (ii) inefficient units can be compared to more appropriate peers [38]. As shown in Figure 2b, using the $\mathrm{BCC}$ model, a higher number of units are efficient $\left(\mathrm{DMU}_{1}, \mathrm{DMU}_{2}\right.$ and $\left.\mathrm{DMU}_{3}\right)$.

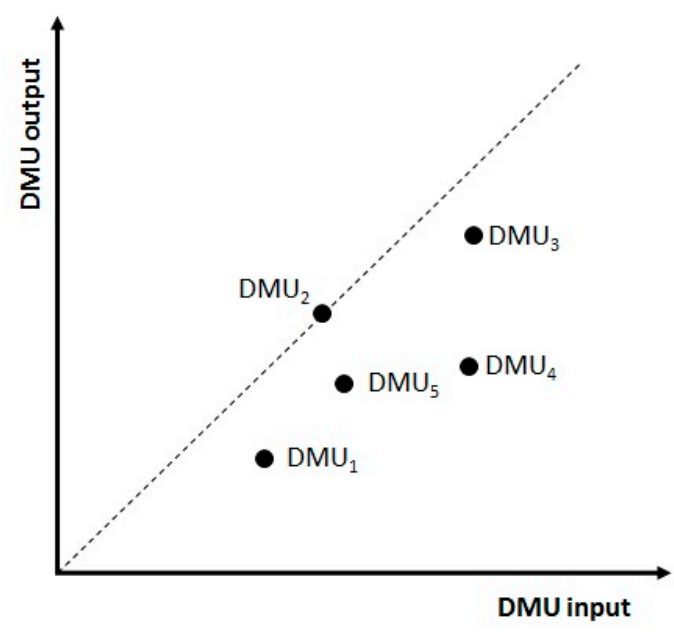

a) CCR model

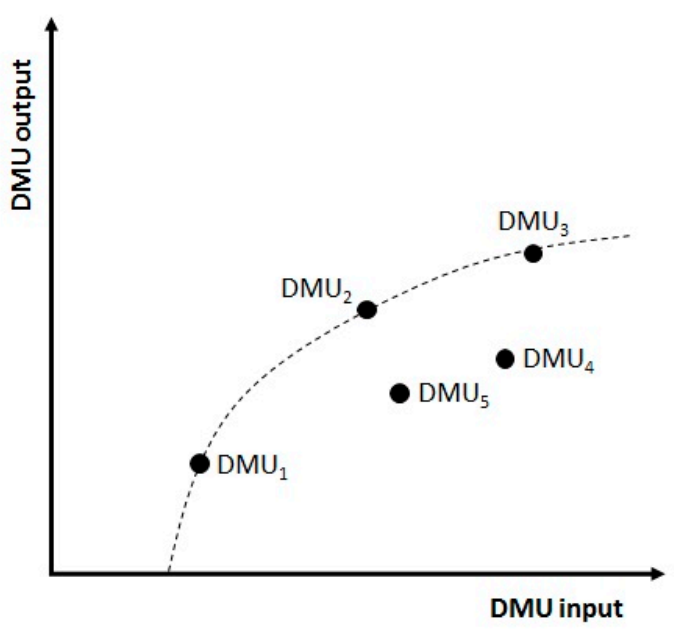

b) BCC model

Figure 2. Graphical representation of the efficiency frontier of the (a) Charnes, Cooper, and Rhodes (CCR) model, and (b) the CCR model modified by Banker et al. (BCC model). Adapted from Hosseinzadeh-Bandbafha et al. [38].

The slacks-based measure (SBM) model is a typical extension of DEA. Although CCR and BCC approaches calculate the efficiencies of the DMUs based on the proportional decrease/increase of inputs/outputs, the SBM model uses the input excess and output shortfall of each DMU to measure its efficiency [59]. Moreover, it is possible to create and estimate models that provide input-oriented or output-oriented approaches for both CRS and VRS envelopments. An input-oriented model attempts to reduce input variables while remaining within the envelopment space. On the other hand, an output-oriented model increases output variables while remaining within the envelopment space [37]. In this study, an input-oriented approach was selected because multiple inputs were used, while there was only one output. 
The DEA linear programming (LP) model (M1) deployed to generate CCR efficiency factors of DMUs is as follows [54]:

M1 (CCR model input-oriented to be solved for each DMU $\mathrm{k}_{0}$ ):

$$
\begin{aligned}
& \min \theta_{C C R}\left(k_{0}\right)=\sum_{j=1}^{n} u_{j} y_{j k_{0}} ; \\
& \text { s.t. } \\
& \sum_{i=1}^{m} v_{i} x_{i k_{0}}=1 ; \\
& \sum_{j=1}^{n} u_{j} y_{j k_{0}}-\sum_{i=1}^{m} v_{i} x_{i k_{0}} \leq 0, \quad k=1, \ldots, K ; j=1, \ldots, n ; i=1, \ldots, m ; \\
& u_{j} \geq 0, \\
& v_{i} \geq 0,
\end{aligned}
$$

where $u_{j}$ is the weight for output $j, v_{i}$ is the weight for input $i, m$ is the number of inputs, $n$ is the number of outputs, $k$ is the number of DMUs, $y_{j k}$ is the amount of output $j$ of DMU $k$, and $x_{j k}$ is the amount of input $\mathrm{i}$ of DMU $\mathrm{k}$.

On the other hand, the DEA LP model deployed to generate BCC efficiency factors of DMUs is as follows [58]:

M2 (BCC model input-oriented to be solved for each DMU $\mathrm{k}_{0}$ ):

$$
\begin{aligned}
& \min \theta_{B C C}\left(\mathrm{k}_{0}\right)=\sum_{j=1}^{n} \mathrm{u}_{\mathrm{j}} \mathrm{y}_{\mathrm{jk}}-\mathrm{u}\left(\mathrm{k}_{0}\right) ; \\
& \text { s.t. } \\
& \sum_{\mathrm{i}=1}^{\mathrm{m}} \mathrm{v}_{\mathrm{i}} \mathrm{x}_{\mathrm{ik}}=1 ; \\
& \sum_{\mathrm{j}=1}^{\mathrm{n}} \mathrm{u}_{\mathrm{j}} \mathrm{y}_{\mathrm{jk}}-\sum_{\mathrm{i}=1}^{\mathrm{m}} \mathrm{v}_{\mathrm{i}} \mathrm{x}_{\mathrm{ik}}-\mathrm{u}_{\left(\mathrm{k}_{0}\right)} \leq 0, \\
& \mathrm{k}=1, \ldots, \mathrm{K} ; \mathrm{j}=1, \ldots, \mathrm{n} ; \mathrm{i}=1, \ldots, \mathrm{m} ; \\
& \mathrm{u}_{\mathrm{j}} \geq 0, \\
& \mathrm{v}_{\mathrm{i}} \geq 0,
\end{aligned}
$$

where $u_{j}$ is the weight for output $j, v_{i}$ is the weight for input $i, m$ is the number of inputs, $n$ is the number of outputs, $k$ is the number of DMUs, $y_{j k}$ is the amount of output $j$ of DMU $k$, and $x_{j k}$ is the amount of input $\mathrm{i}$ of DMU $\mathrm{k}$.

To combine the LCA and DEA methods, a five-step procedure was followed [60,61]: (i) individual LCI for each of the DMUs; (ii) LCIA for every DMU included in the inventory (in this case, using the PED and GWP indicators, as explained in Section 2.1); (iii) determination of the operational efficiency for each DMU; (iv) LCIA of the target DMUs; (v) quantification of the environmental consequences of operational inefficiencies [42].

\section{Case Study: The Spanish Food Basket}

\subsection{Goal and Scope}

The Spanish Agency of Food Security and Nutrition (AECOSAN), along with the Spanish Society of Community Nutrition (SENC), is the institution that sets the nutritional recommendations for the Spanish population. These recommendations take into account the main diet-related public health challenges, as well as cultural habits of the Spanish population, to promote healthy eating and regular physical activity [62].

In this study, a basket of products was selected based on the consumption data reported by the Ministry of Agriculture, Fisheries, and Food (MAPAMA) [63]. These food commodities were classified 
according to eleven categories following the Food and Agriculture Organization of the United Nations (FAOSTAT) classification: eggs, meat and animal fat, fish and seafood, dairy, cereals, sweets, pulses, vegetable oils, vegetables, fruits, and roots and tubers. The food commodities considered in each category are collected in Table 1.

The goal and scope of this study was to assess the energetic and environmental efficiency of the Spanish food basket by means of the combination of LCA and DEA approaches. An additional goal of this analysis was to determine whether the use of DEA methodology is a viable tool for assessing the energy efficiency of food systems with FLW. The results are expected to provide an overview regarding the energy efficiency of the different food categories under study with the aim of identifying the most inefficient and the stages where improvement measures should be applied.

Table 1. Food commodities included in the study.

\begin{tabular}{cl}
\hline Food Category & \multicolumn{1}{c}{ Commodities Included } \\
\hline Cereals & Wheat, rice, maize, and others \\
Roots and tubers & Potatoes \\
Sugar & Sugar \\
Vegetable oils & Sunflower seed oil, palm oil, olive oil, and others \\
Vegetables & Tomatoes, onions, and others \\
Fruit & Oranges and mandarins, grapes (excluding grapes for winemaking), apples, \\
Pulses & and others \\
Meat and animal fat & Beans, peas, and others \\
Fish and seafood & Beef, pork, lamb, and poultry \\
Dairy & Fish and seafood \\
Eggs & Milk, cheese, and butter \\
\hline
\end{tabular}

\subsection{Function, Functional Unit, and System Boundaries}

The methodology proposed included three main parts: LCA, EROI, and the combination of LCA and DEA. Therefore, the function of the study was the estimation of the environmental impacts of the Spanish food basket and the determination of its energy efficiency. To quantify this function, it was necessary to define an FU to which inputs and outputs would be referred. In this case, the FU was described as the food basket with the representative food products consumed by a Spanish citizen in a year, covering the daily energy requirement of $2000 \mathrm{kcal}$ of an adult.

The system boundaries comprise the entire supply chain of a food system following Garcia-Herrero et al. [4] (see Figure 3), i.e., agricultural production, postharvest and storage, industrial processing, distribution (i.e., retail/wholesale), and consumption. The consumption stage was divided into household consumption and related extradomestic consumption.

\subsection{Life-Cycle Inventory (LCI)}

An extensive LCI was built up using data from the literature (for more details, see Batlle-Bayer et al. [64]) and the PE GaBi database [53]. The food balance sheet and the unavoidable FLW percentages of each food category were collected from García-Herrero et al. [3], where production values were mainly sourced from Eurostat [65-68]. Imported food products were taken into account based on trade statistics compiled by the Spanish Tax Agency (AEAT) [69]. The food balance sheet for Spain in 2015 and the FLW percentages are available in Sections S1 and S2 in the Supplementary Materials (SM).

For transportation, 400-km and 100-km distances to wholesale and retailers were assumed, respectively. Electricity consumption for retail storage was considered, assuming two days of storage for products requiring cooling conditions, and 15 days under freezing conditions. Transport to home was estimated based on Milà i Canals et al. [70]. Regarding home storage, data from the LCA Food 
Database was used [71]. For cooking, energy factors of Foster et al. [72] were taken (for more details, see Batlle-Bayer et al. [64]).

On the other hand, nutritional data for the EROI estimation were obtained from the food composition tables of the Institute for Education in Nutrition and Dietetics from Spain (CESNID) [73]. Such tables are registered in the FAO's International Network of Food Data Systems [74]. The nutritional content for each food category under study is collected in Section S3 in the Supplementary Materials.

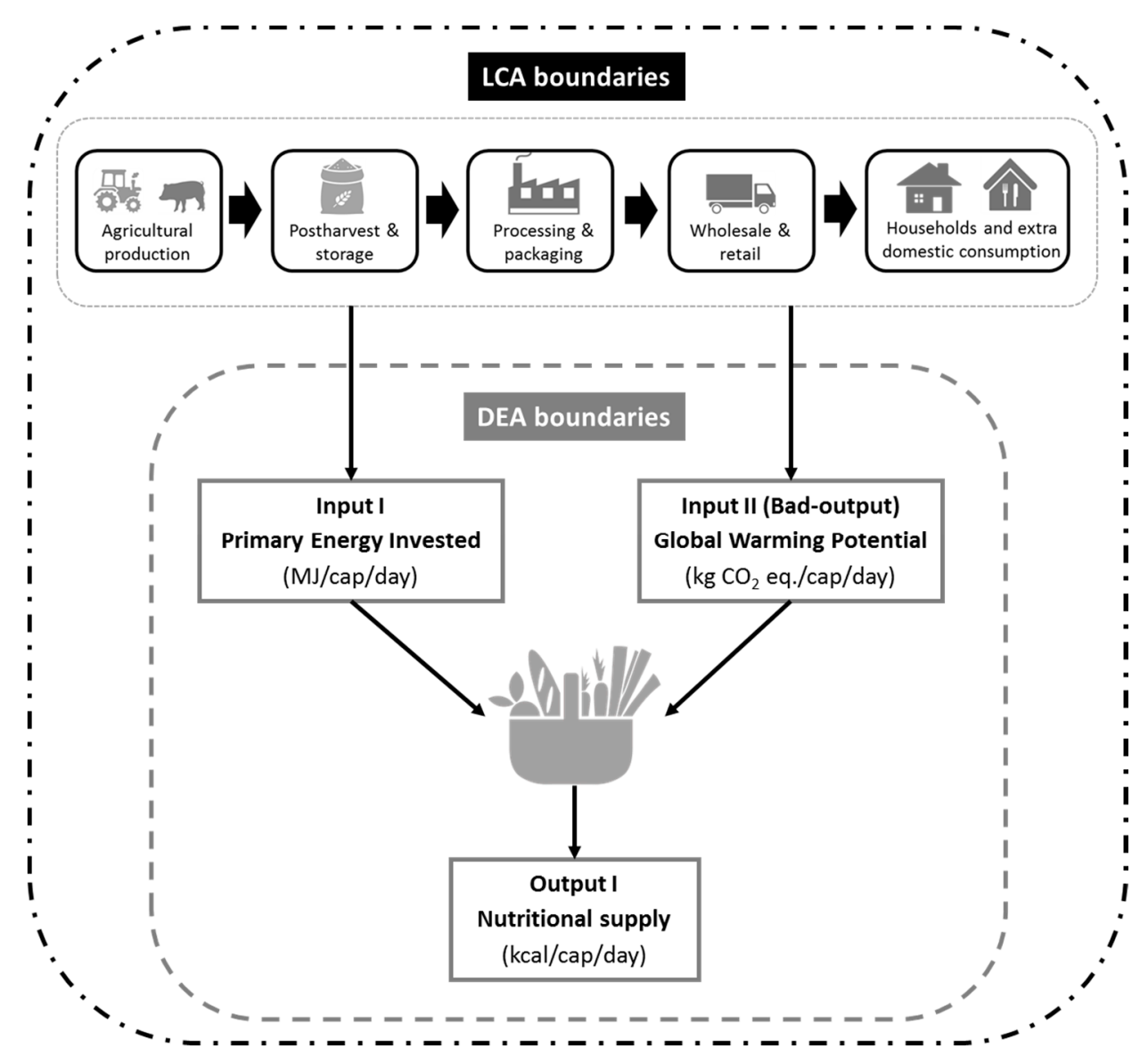

Figure 3. System boundaries for the Spanish food basket using a life-cycle assessment (LCA)/data envelopment analysis (DEA) approach.

\subsection{Selection of the DEA Model}

The selected DEA model was the slacks-based measure of efficiency (SBM). The choice of model was based on its flexibility concerning the computation of the DMUs irrespective of the units of measure used for the different inputs/outputs [42]. Moreover, for the sake of further discussion, the CRS and VRS approaches were computed in parallel in the current study under an input-oriented approach.

\subsection{Inputs and Output Selection for the DEA Matrix}

One DEA matrix composed of 11 DMUs was computed in this study. The number of DMUs under study must satisfy Equation (4). Each DMU included two different inputs (see Figure 3). As input 1, the primary energy invested in food production was computed in MJ/cap/day, whereas the GWP was considered as input 2 . As mentioned previously, an input-oriented approach was based on the assumption that inputs have to be minimized and outputs have to be maximized. However, in some situations, undesirable (bad) inputs and outputs may be presented in the production process [75]. In 
this case, the GWP was a bad output that was computed as an input to be minimized. Finally, the nutritional energy supply was computed in $\mathrm{kcal} / \mathrm{cap} /$ day as output.

$$
n \geq \max \{m \times s, 3 \times(m+s)\},
$$

where $m$ is the number of inputs used in the DEA study, and $s$ is the number of outputs involved.

\section{Results and Discussion}

Following the methodology described in Section 2, the LCA of the 11 food categories selected was performed, and the PED and GWP were calculated. These values were obtained from a previous study developed by Batlle-Bayer et al. [64]. As shown in Table 2, the total energy invested in food production daily amounts to around 19,500 kcal for an average Spanish citizen. This involves an emission of close to $4 \mathrm{~kg}$ of $\mathrm{CO}_{2}$ equivalent per day, with meat production as the most responsible: $28 \%$ for PED and $42 \%$ in terms of $\mathrm{CO}_{2}$ equivalent emissions. Dairy, and fish and seafood are the second main categories contributing to GWP, each representing $12 \%$ of total emissions. Results suggest a high correlation between the investment of energy along the FSC and the generation of GHG emissions, owing to the high dependency of the energy matrix on fossil fuels. Conversely, this is not directly related to the nutritional energy provided to consumers. As displayed in Table 1, the major contributors to the Spanish average diet are vegetable oils and cereals, responsible for nearly half of the energy supply. However, the contribution of meat to nutritional energy supply is relegated to less than $12 \%$, with eggs as the food category providing the lowest amount of nutritional energy to consumers (2\%). These results are in agreement with data reported by the European Commission [76], which confirm that livestock products, such as meat, fish and seafood, and dairy products, incorporate a substantial amount of energy; in addition, the consumption of dairy and meat products has a major role in GHG emissions.

Table 2. Energy invested from cradle to plate for the food categories under study, related $\mathrm{CO}_{2}$ eq. emissions, and nutritional energy provided to consumer. PED—primary energy demand; GWP—global warming potential; FLW—food losses and waste.

\begin{tabular}{|c|c|c|c|c|c|}
\hline Food Category & $\begin{array}{c}\text { PED } \\
\text { (kcal/cap/d) }\end{array}$ & $\begin{array}{c}\text { Energy Provided } \\
\text { to Consumer } \\
(\text { kcal })\end{array}$ & $\begin{array}{c}\mathrm{GWP} \\
\left(\mathrm{g} \mathrm{CO}_{2}\right. \\
\text { eq./cap/d) }\end{array}$ & $\begin{array}{c}\text { Embodied } \\
\text { Energy in FLW } \\
\text { (kcal/cap/d) }\end{array}$ & $\begin{array}{c}\text { Embodied GWP in } \\
\text { FLW }\left(\mathrm{g} \mathrm{CO}_{2}\right. \\
\text { eq./cap/d) }\end{array}$ \\
\hline Meat & 5465 & 261 & 1673 & 1162 & 378 \\
\hline $\begin{array}{l}\text { Fish and } \\
\text { seafood }\end{array}$ & 3170 & 99 & 468 & 852 & 128 \\
\hline Cereals & 2717 & 456 & 372 & 1042 & 143 \\
\hline Sweets & 156 & 103 & 28 & 35 & 8 \\
\hline Pulses & 490 & 58 & 85 & 142 & 27 \\
\hline Vegetable Oils & 717 & 461 & 158 & 150 & 39 \\
\hline Vegetables & 3297 & 72 & 261 & 745 & 70 \\
\hline Fruits & 690 & 159 & 159 & 171 & 52 \\
\hline
\end{tabular}

When considering FLW, it was observed that embodied energy waste duplicates the daily energy supplied to consumers ( $4685 \mathrm{kcal} / \mathrm{cap} / \mathrm{d}$ ). As shown in Figure 4a, the largest contributor to this fact is the meat category, accounting for $25 \%$. This is directly related to the unnecessary emission of $\mathrm{CO}_{2}$ eq., which also contributes $40 \%$ to the total GWP (Figure $4 \mathrm{~b}$ ). It is followed by cereals and fish and seafood categories, for which a $22 \%$ and $18 \%$ embodied energy waste was estimated, respectively, whereas a $15 \%$ and $12 \%$ of embodied GWP waste was calculated. 


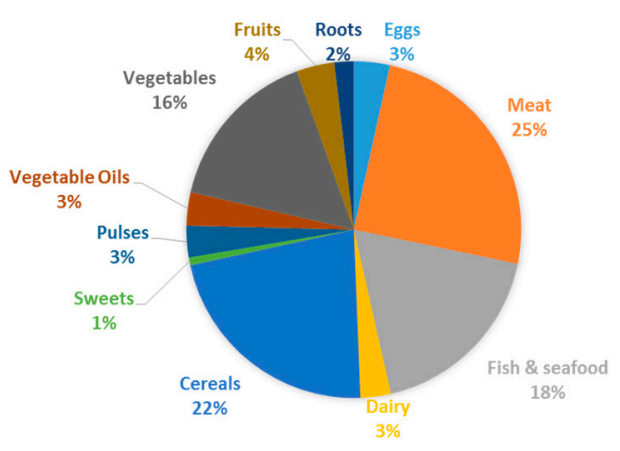

a) Embodied energy

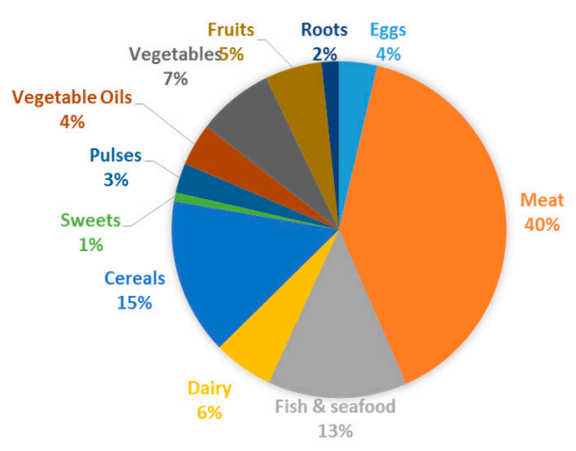

b) Embodied GWP

Figure 4. Contribution of each food category in the average Spanish diet to the (a) embodied energy, and (b) embodied global warming potential (GWP).

These findings suggest the need for estimating the efficiency of the Spanish agri-food system. As a first approach, the EROI indicator was used to estimate the energetic efficiency. As displayed in Table 3, the maximum EROI was observed for sweets and vegetable oils, which means that such food categories are the most efficient from an energy perspective. These results also suggest the need of studying more in-depth nutrients that should be either encouraged or limited, in order to provide a nutritional efficiency perspective. Results also show that animal-based products such as eggs, meat, and fish present the lowest EROI values (3.1-4.0\%), which agree with the study of Pelletier et al. [5], where an eightfold difference between animal- and plant-based products was determined. An exception was observed in our results for vegetables. This is mainly due to the inclusion of processed commodities in this category, particularly tomato sauce, which exhibits an EROI value of $1.2 \%$.

Table 3. Energy return on investment (EROI) values for food categories in the Spanish diet.

\begin{tabular}{ccccccc}
\hline Food Category & Eggs & Meat & Fish and Seafood & Dairy & Cereals & Sweets \\
\hline EROI $(\%)$ & 3.90 & 3.96 & 3.14 & 20.52 & 16.79 & 66.00 \\
\hline Food category & Pulses & Vegetable Oils & Vegetables & Fruits & Roots \\
\hline EROI $(\%)$ & 11.75 & 64.27 & 2.18 & 23.05 & 16.10 \\
\hline
\end{tabular}

However, these efficiency results do not consider the environmental impacts of food production along the supply chain. For this reason, DEA was combined with LCA, allowing a wider scope of the efficiency of the Spanish agri-food system to be provided. To perform an LCA/DEA analysis, it is firstly necessary to elaborate the DEA matrix. Table 4 represents the DEA matrix, composed of 11 DMUs, with each one represented by two inputs and one output, as explained in Section 3.4.

Table 4. Data envelopment analysis (DEA) matrix under study. DMU—decision-making unit.

\begin{tabular}{ccccc}
\hline \multirow{2}{*}{ Food Category } & DMU & Input 1 & Bad Output (Input 2) & Output 1 \\
\cline { 2 - 4 } & & $\begin{array}{c}\text { Primary Energy } \\
\text { Invested (MJ/cap/day) }\end{array}$ & $\begin{array}{c}\text { GWP (g CO } \mathbf{2}_{2} \\
\text { eq/cap/day) }\end{array}$ & $\begin{array}{c}\text { Nutritional Supply } \\
\text { (kcal/cap/day) }\end{array}$ \\
\hline Eggs & 1 & 4.43 & 221 & 41.3 \\
Meat & 2 & 22.84 & 1672 & 216 \\
Fish and seafood & 3 & 13.25 & 468 & 99.7 \\
Dairy & 4 & 5.90 & 496 & 289 \\
Cereals & 5 & 11.36 & 371 & 456 \\
Sweets & 6 & 0.53 & 28.5 & 103 \\
Pulses & 7 & 2.05 & 85.0 & 57.6 \\
Vegetable Oils & 8 & 3.00 & 158 & 461 \\
Vegetables & 9 & 13.78 & 154 & 71.7 \\
Fruits & 10 & 2.84 & 50.5 & 151 \\
Roots & 11 & 1.38 & 53.1 \\
\hline
\end{tabular}


DEA Frontier was the software used for the computation of the DEA matrix [77]. Results using CRS and VRS perspectives were compared and are shown in Figure 5, which includes the efficiency score for each DMU. A food category was considered inefficient with an efficiency score $\phi<1$, whereas $\varphi=1$ represented an efficient food category. According to that, when the CRS perspectives were considered, one food category was efficient (sweets), while a 0.97 efficiency was observed for vegetable oils (see Figure 5a). The CRS approach presented a wide range of efficiencies, between 0.06 and 0.97 . Egg production was the least efficient food category, followed by fish, meat, and vegetables, with similar efficiencies ranging from 0.06 to 0.08 . On the other hand, when the VRS model was applied, a total of two food categories were considered efficient (sweets and vegetable fats; see Figure $5 b$ ). Despite the fact that the VRS approach presented an additional efficient DMU, the range of efficiencies was lower than when using a CRS perspective, ranging from 0.06 to 0.56 . Finally, the average efficiencies (including efficient DMUs) were similar: $0.33 \pm 0.34$ for CRS and $0.40 \pm 0.34$ for VRS. Some authors state that using a VRS approach rather than a CRS formulation leads to a higher number of efficient DMUs since the constraint set for CRS is less restrictive and, consequently, lower efficiency scores are possible [78]. In addition, the convexity constraint added in the VRS simply guarantees that each DMU is only compared to others of similar size [43]. Therefore, considering that the unit of reference (i.e., DMU) is, in each case, a different food category and that the food categories inventoried in this study present different characteristics, we considered that the use of the VRS approach should prevail.

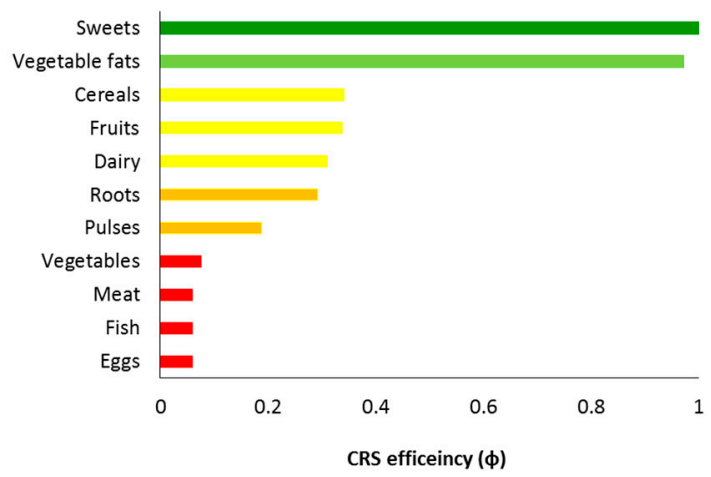

a) CRS model

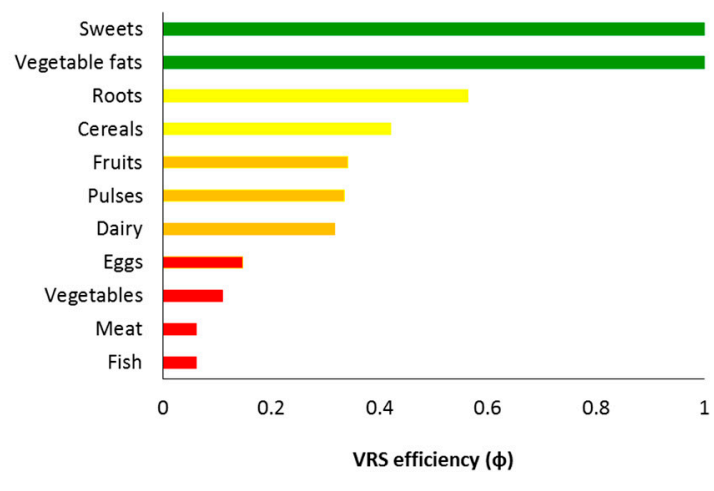

b) VRS model

Figure 5. Efficiency $(\phi)$ score of the selected food categories (i.e., decision-making units (DMUs)) using the (a) constant return to scale (CRS) model, and (b) variable return to scale (VRS) model.

The previous findings agree with the pattern observed for the EROI assessment. While this can be taken as a verification of both approaches, DEA also provides a further exploration of the operational inefficiencies and the improvement actions of the system under study. Hence, the DEA model was also used to formulate new virtual and efficient values for the inputs of the inefficient DMUs, by projecting the inefficient scores on the efficient targets established. Both PED and GWP were subjected to minimization while maintaining the same nutritional supply.

Figures 6 and 7 compare the current environmental impacts of the different DMUs with the target PED and GWP calculated with the LCA/DEA methodology. In other words, it presents the environmental savings that would be reached in these DMUs if they were to operate under the efficient conditions projected in the computed matrix. In this regard, when the CRS perspective was used, primary energy invested savings ranged from $2.83 \%$ to $96.7 \%$, while, when the VRS approach was used, reductions ranged from $52.9 \%$ to $95.3 \%$. The highest reductions were obtained by the most inefficient food categories (i.e., vegetables, meat, fish, and eggs). On the other hand, GWP savings followed the same trend, ranging from $19 \%$ to $96.4 \%$ for CRS and from $43.6 \%$ to $95.8 \%$ for VRS. Similarly, the highest reductions were also reached by vegetables, meat, fish, and eggs. 


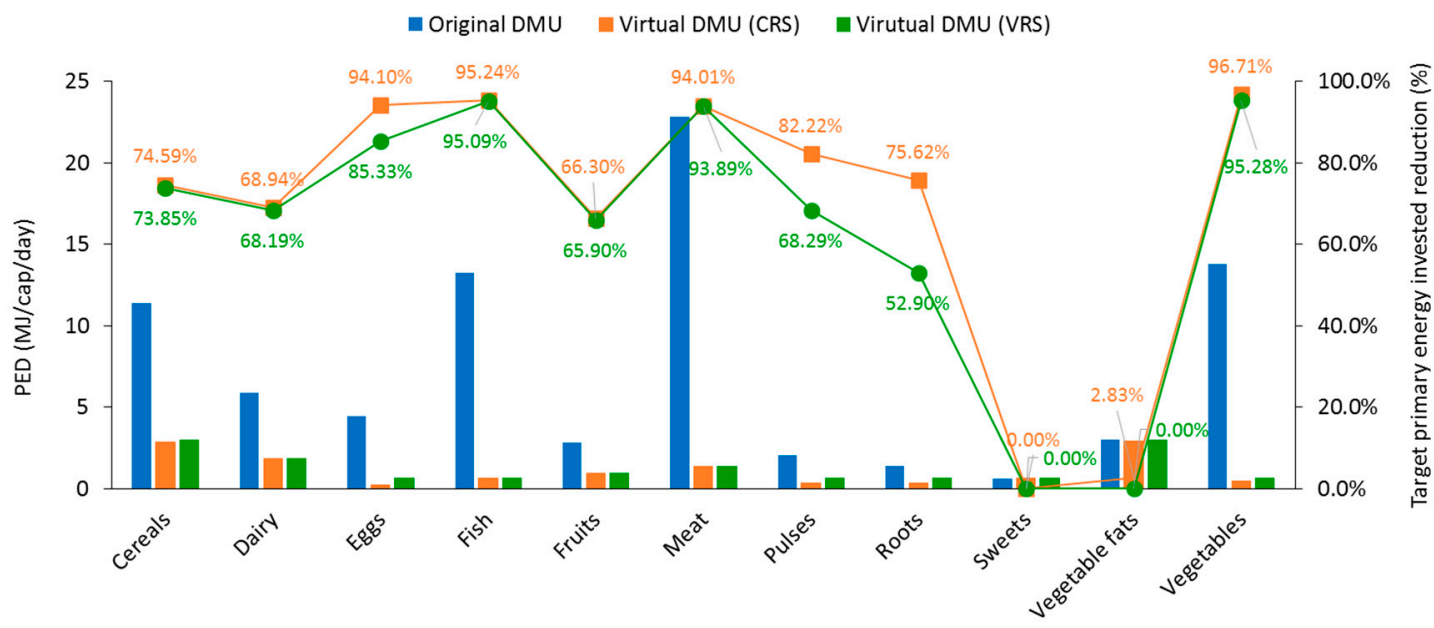

Figure 6. Primary energy invested (PED) for original DMUs (blue bar) and virtual targets for the CRS model (orange bar) and VRS model (green bar). The lines represent the overall environmental improvements for the CRS model (orange line) and VRS model (green line).

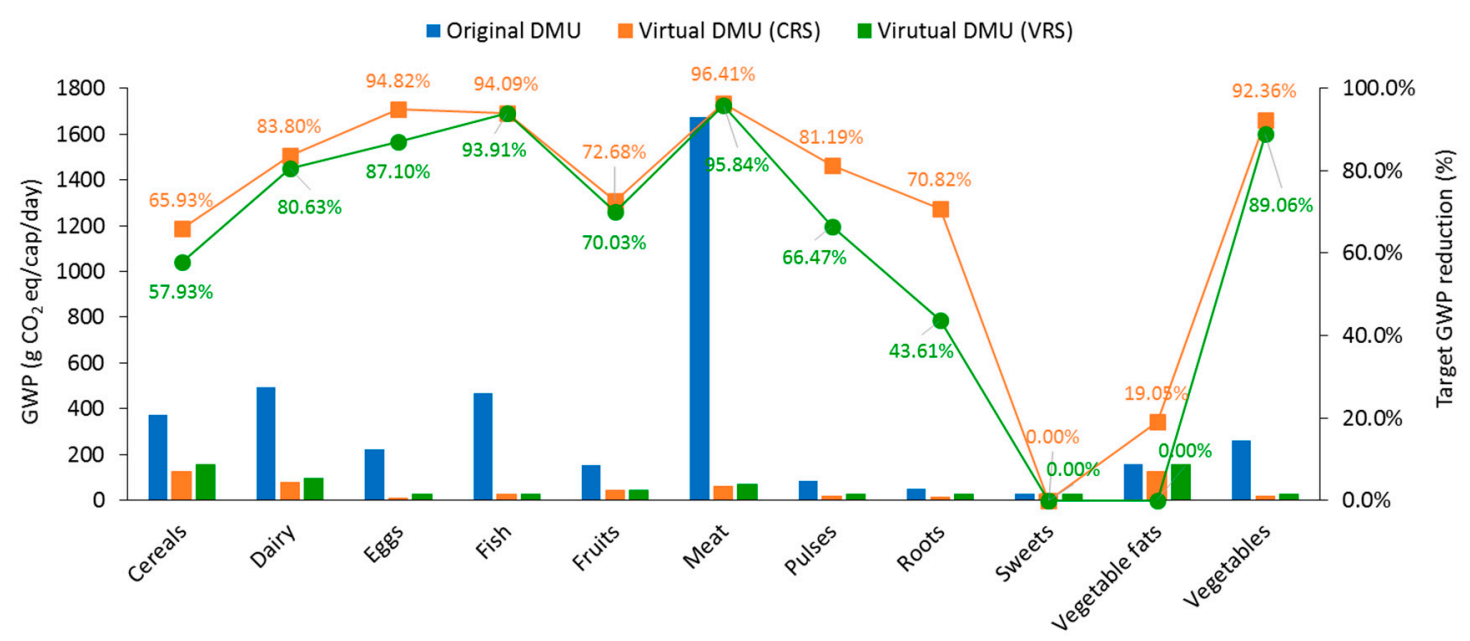

Figure 7. Global warming potential (GWP) for original DMUs (blue bar) and virtual targets for the CRS model (orange bar) and VRS model (green bar). The lines represent the overall environmental improvements for the CRS model (orange line) and VRS model (green line).

The results suggest that the planification of citizens' diet may affect the quantity of embodied energy waste and related environmental impacts. For this reason, specific strategies should be addressed to the categories revealing larger inefficiency scores, such as meat, eggs, fish, and vegetables, which all have better nutritional reputation than sweets or processed cereals. Figure 8 displays the contribution of each stage of the FSC to the PED for eggs, meat, fish and seafood, and vegetable categories. As stated by Batlle-Bayer et al. [64], in terms of the life-cycle processes, the primary production phases were the major contributors to the PED for eggs $(85 \%)$, meat $(65 \%)$, and fish and seafood $(59 \%)$, while the household stage was the main contributor for vegetables (52\%). These results are related to the production of feed in the case of eggs and meat production [60]. According to Ghasempour and Ahmadi [79], the production of feed (corn, soybean, and wheat), as well as the poultry equipment, used in the production of eggs is associated wuth the most energy consumption, whereas Skunca et al. [17] suggested the use of grain legumes as a protein source in feed instead of soybean-based ingredients. This fact could decrease the resource consumption since the cultivation of grain legumes does not require mineral fertilizer application. Moreover, in the case of beef, the use of electricity and diesel during the suckling cow-calf stage was also significant in the primary production phase [64]. 
Other authors, such as Avadí et al. [80,81], Laso et al. [22], and Vázquez-Rowe et al. [82] assessed the life cycle of processed fish products identifying the fishery stage as one of the most energy-intensive due to the use of fossil fuels. Batlle-Bayer et al. [64] analyzed eight fish and seafood species (i.e., mussels, shrimps and prawns, Atlantic mackerel, European hake, sardines, salmon, tuna, and octopus), identifying the use of diesel as the main contributor (around 98\%) in the fishery stage, and the use of electricity (around 97\%) in the culture stage (mussels farming).

On the other hand, for vegetables, several foods were considered (tomato, lettuce, and veggies). The fact that household consumption was the stage with the highest contribution to PED was due to the use of energy when cooking veggies (i.e., boiling and frying) and cold storage for preserving their shelf life. However, the agricultural production stage for vegetables was also important, representing $26 \%$ of total PED, due to the cultivation of lettuce, in particular, the use of diesel for machinery. In fact, although the amount of PED required for meat, fish and seafood, and vegetable consumption is similar (Table 4), it was distributed in different stages. Finally, the processing stage represented $19 \%$ of the total impact due to the inclusion of processed products, such as tomato processed products, which use fuel oil and electricity in their processing.

Agricultural production $\square$ Processing $\square$ Distribution $\square$ Households $\square$ Transport

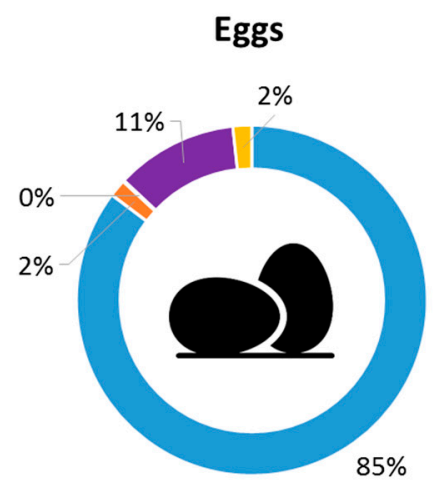

Fish \& seafood

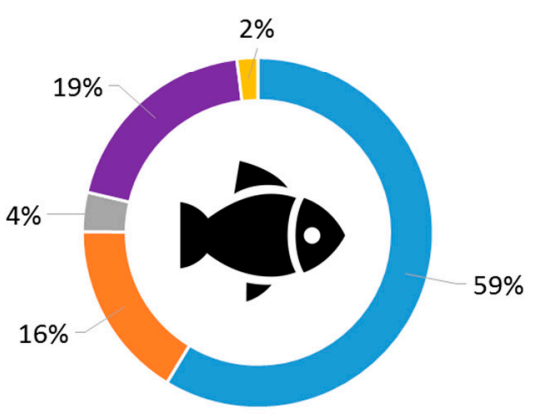

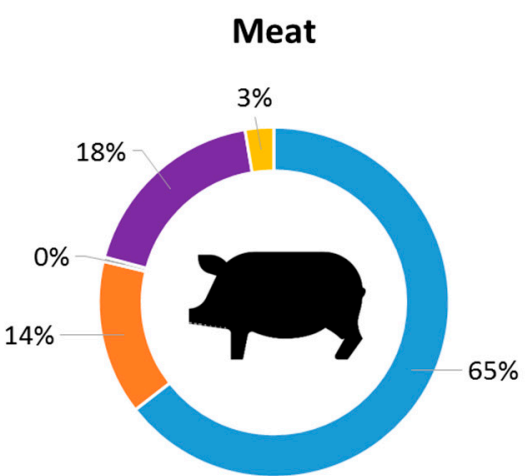

Vegetables

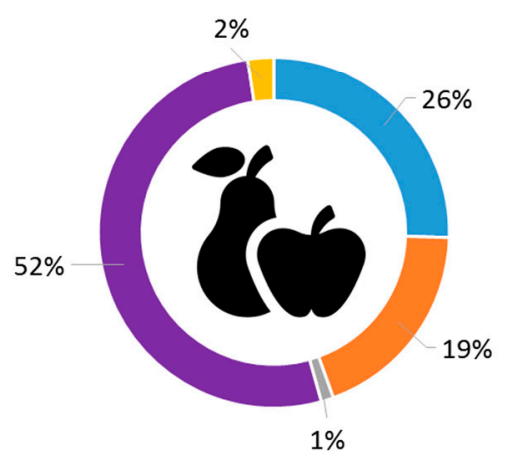

$1 \%$

Figure 8. Distribution of the primary energy demand (PED) between the different stages of the food supply chain for the most inefficient food categories: eggs, meat, fish and seafood, and vegetables.

\section{Conclusions}

Food systems are heavily reliant on energy resources, especially non-renewable resources. This causes significant amounts of GHG emissions. In this study, the efficiency of the Spanish agri-food system was addressed from an energy and environmental perspective. Firstly, an LCA was performed to determine the PED and GWP impact results of the food basket with the representative food products consumed in and out of home by a Spanish adult in a year. Thereafter, the EROI indicator was 
used to perform an energy-based efficiency assessment. Finally, DEA was coupled with LCA to include environmental aspects in the efficiency assessment. Both approaches provided similar results, suggesting a high correlation between PED and $\mathrm{CO}_{2}$ eq. emissions. Best results were obtained for the categories of sweets and vegetable oils $(\phi=1)$, while vegetables, fish, eggs, and meat exhibited the lowest efficiency, below 0.1 . As expected, animal-based products required more energy resources in their production than vegetable-based products. However, it is important to mention that these types of food (i.e., sweets and vegetable oils) are considered "empty kcals", and their nutritional value is very low, whereas eggs, meat, and fish are most valuable in terms of nutritional value. Therefore, it would be interesting to considering other nutrients, such as proteins, in future assessments. On the other hand, the unexpected results for vegetables are due to the inclusion of processed products in this category. On average, approximately 70\% energy-saving potential is estimated for the Spanish agri-food system if it were to be efficient, with a similar reduction in related GHG emissions. These results suggest the need for improving the efficiency of the FSC by introducing circular economy strategies, such as establishing appropriate food waste management measures and the consequent reduction of FLW. Therefore, the methodology proposed is a useful tool for promoting the circular economy of food. The introduction of nutritional- and energy-based criteria, in addition to the environmental pillar, provides an integrated framework for proposing integrated reduction targets. However, as ongoing research, other criteria, such as economic and social aspects, could be considered. From the DEA results, it is possible to define specific strategies for the categories revealing larger inefficiency scores, such as meat, eggs, fish, and vegetables. In terms of the life-cycle processes, the primary production phases were the major contributors to PED for eggs (85\%), meat (65\%), and fish and seafood (59\%), due to the production of feed (corn, soybean, and wheat) in the case of eggs and meat, and the use of diesel and electricity in the fishery and cultivation stages, respectively. On the other hand, the household stage was the main contributor for vegetables (52\%) due to the use of electricity for cooking and cooling.

Finally, we can establish that DEA is a useful tool for energy optimization, identifying efficient and inefficient food systems. This approach may be adopted by institutions, policy-makers, and producers as a helpful instrument to support decision-making and improve the sustainability of agri-food systems.

Supplementary Materials: The following are available online at http://www.mdpi.com/1996-1073/11/12/ 3395/s1. Section S1: Food Balance Sheet Construction; Section S2: Avoidable and Unavoidable Food Loss Calculation; Section S3: Nutritional Food Loss Calculation; Section S4: Example of Calculations According to the Methodologies Presented in Section 2.

Author Contributions: Conceptualization, R.A.; investigation, I.G.-H., J.L., and D.H.; methodology, L.B.-B., and I.V.-R.; formal and technical analysis, I.V.-R., J.L., P.F., A.B., A.I., L.B.-B., and R.A.; supervision, M.M., J.L., and R.A.; writing and editing of manuscript, I.G.-H. and J.L.

Funding: This work was carried out under the financial support of the Project Ceres-Procom: food production and consumption strategies for climate change mitigation (CTM2016-76176-C2-1-R) (AEI/FEDER, UE) financed by the Ministry of Economy and Competitiveness of the Government of Spain.

Acknowledgments: The authors want to acknowledge the Industrial PhD Program 2017 (BOC N'200 18/10/2017) and to the UNESCO Chair in Life Cycle and Climate Change.

Conflicts of Interest: The authors declare no conflict of interest.

\section{References}

1. Pimentel, D.; Pimentel, M.H. (Eds.) Food, Energy and Society; CRC press: Boston, MA, USA, 2008.

2. Bolandnazar, E.; Keyhani, A.; Omid, M. Determination of efficient and inefficient greenhouse cucumber producers using Data Envelopment Analysis approach, a case study: Jiroft city in Iran. J. Clean. Prod. 2014, 79, 108-115. [CrossRef]

3. Cucchiella, F.; D'Adamo, I.; Gastaldi, M.; Miliacca, M. Efficiency and allocation of emission allowances and energy consumption over more sustainable European economies. J. Clean. Prod. 2018, 182, 805-817. [CrossRef] 
4. Garcia-Herrero, I.; Hoeh, D.; Margallo, M.; Laso, J.; Bala, A.; Batlle-Bayer, I.; Fullana, P.; Vázquez-Rowe, I.; Gonzalez, M.J.; Durá, M.J.; et al. On the estimation of potential food waste reduction to support sustainable production and consumption policies. Food Policy 2018, 80, 24-38. [CrossRef]

5. Pelletier, N.; Audsley, E.; Brodt, S.; Garnett, T.; Henriksson, P.; Kendall, A.; Troell, M. Energy intensity of agriculture and food systems. Annu. Rev. Environ. Resour. 2011, 36, 233-246. [CrossRef]

6. OECD. Improving energy efficiency in the Agro-Food chain. In OECD Green Growth Studies; OECD Publishing: Paris, France, 2017.

7. Morone, P.; Falcone, P.M.; Lopolito, A. How to promote a new and sustainable food consumption model: A fuzzy cognitive map study. J. Clean. Prod. 2019, 208, 563-574. [CrossRef]

8. Vora, N.; Shah, A.; Bilec, M.M.; Khanna, V. Food-energy-water nexus: Quantifying embodied energy and GHG emissions from irrigation through virtual water transfers in food trade. ACS Sustain. Chem. Eng. 2017, 5, 2119-2128. [CrossRef]

9. Khoshroo, A.; Mulwa, R.; Emrouznejad, A.; Arabi, B. A non-parametric Data Envelopment Analysis approach for improving energy efficiency of grape production. Energy 2013, 63, 189-194. [CrossRef]

10. Arushanyan, Y.; Björklund, A.; Eriksson, O.; Finnveden, G.; Söderman, M.L.; Sundqvist, J.; Stenmarck, A. Environmental Assessment of Possible Future Waste Management Scenarios. Energies 2017, 10, 247. [CrossRef]

11. Marique, A.; Rossi, B. Cradle-to-grave life-cycle assessment within the built environment: Comparison between the refurbishment and the complete reconstruction of an office building in Belgium. J. Environ. Manag. 2018, 224, 396-405. [CrossRef]

12. Ingrao, C.; Messineo, A.; Beltramo, R.; Yigitcanlar, T.; Iioppolo, G. How can life cycle thinking support sustainability of buidings? Investigating life cycle assessment applications for energy efficiency and environmental performance. J. Clean. Prod. 2018, 201, 556-569. [CrossRef]

13. Berg, F.; Fuglseth, M. Life cycle assessment and historic buidings: Energy-efficiency refurbishment versus new construction in Norway. J. Arch. Conserv. 2018, 24, 152-167.

14. Li, H.; Feng, K. Life cycle assessment of the environmental impacts and energy efficiency of an integration of sludge anaerobic digestion and pyrolysis. J. Clean. Prod. 2018, 195, 476-485. [CrossRef]

15. Sundaram, S.; Kolb, G.; Hessel, V.; Wang, Q. Energy-Efficient Routes for the Production of Gasoline from Biogas and Pyrolysis Oil-Process Design and Life-Cycle Assessment. Ind. Eng. Chem. Res. 2017, 56, 3373-3387. [CrossRef] [PubMed]

16. Carrasquer, B.; Uche, J.; Martinez-Gracia, A. A new indicator to estimate the efficiency of water and energy use in agro-industries. J. Clean. Prod. 2017, 143, 462-473. [CrossRef]

17. Skunca, D.; Tomasevic, I.; Nastasijevic, I.; Tomovic, V.; Djekic, I. Life cycle assessment of the chicken meat chain. J. Clean. Prod. 2018, 184, 440-450. [CrossRef]

18. Pires-Gaspar, J.; Dinis-Gaspar, P.; Dinho da Silva, P.; Simoes, M.P.; Espirito-Santo, C. Energy Life-Cycle Assessment of Fruit Products-Case Study of Beira Interior's Peach (Portugal). Sustainability 2018, 10, 3530. [CrossRef]

19. Murphy, D.J.; Carbajales-Dale, M.; Moeller, D. Comparing Apples to Apples: Why the Net Energy Analysis Community Needs to Adopt the Life-Cycle Analysis Framework. Energies 2016, 9, 917. [CrossRef]

20. Vázquez-Rowe, I.; Villanueva-Rey, P.; Moreira, M.T.; Feijoo, G. Edible Protein Energy on Investment Ratio (ep-EROI) for Spanish Seafood Products. AMBIO 2014, 43, 381-394. [CrossRef]

21. Pelletier, N.; Tyedmers, P. An ecological economic critique of the use of market information in life cycle assessment research. J. Ind. Ecol. 2011, 15, 342-354. [CrossRef]

22. Laso, J.; Vázquez-Rowe, I.; Margallo, M.; Crujeiras, R.M.; Irabien, A.; Aldaco, R. Life cycle assessment of European anchovy (Engraulis encrasicolus) landed by purse seine vessels in northern Spain. Int. J. Life Cycle Assess. 2018, 23, 1107-1125. [CrossRef]

23. Laso, J.; Margallo, M.; García-Herrero, I.; Fullana, P.; Bala, A.; Gazulla, C.; Polettini, A.; Kahhat, R.; Vázquez-Rowe, I.; Irabien, A.; et al. Combined application of life cycle assessment and linear programming to evaluate food waste-to-food strategies: Seeking for answers in the nexus approach. Waste Manag. 2018, 80, 186-197. [CrossRef] [PubMed]

24. Tyedmers, P. Energy consumed by North Atlantic fisheries. In Fisheries Impacts on North Atlantic Ecosystems: Catch, Effort and National/Regional Datasets; Zeller, D., Watson, R., Pauly, D., Eds.; Fisheries Centre Research Reports; Fisheries Centre, University of British Columbia: Kelowna, BC, Canada, 2001; Volume 9. 
25. Ramos, S.; Vázquez-Rowe, I.; Artetxe, I.; Moreira, M.T.; Feijoo, G.; Zufia, J. Environmental assessment of the Atlantic mackerel (Scomber scombrus) season in the Basque Country. Increasing the timeline delimitation in fishery LCA studies. Int. J. Life Cycle Assess. 2011, 16, 599-610. [CrossRef]

26. Cancino-Espinoza, E.; Vázquez-Rowe, I.; Quispe, I. Organic quinoa (Chenopodium quinoa L.) production in Peru: Environmental hotspots and food security considerations using Life Cycle Assessment. Sci. Total Environ. 2018, 637-638, 221-232. [CrossRef]

27. Pérez Neira, D.; Soler Montiel, M.; Delgado Cabeza, M.; Reigada, A. Energy use and carbon footprint of the tomato production in heated multi-tunnel greenhouses in Almeria within an exporting agri-food system context. Sci. Total Environ. 2018, 628-629, 1627-1636. [CrossRef] [PubMed]

28. Masuda, K. Energy Efficiency of Intensive Rice Production in Japan: An Application of Data Envelopment Analysis. Sustainability 2018, 10, 120. [CrossRef]

29. Mardani, A.; Streimikiene, D.; Balezentis, T.; Zameri Mat Saman, M.; Nor, K.; Khoshnava, S. Data Envelopment Analysis in Energy and Environmental Economics: An Overview of the State-of-the-Art and Recent Development Trends. Energies 2018, 11, 2002. [CrossRef]

30. Lee, W.S.; Lee, K.P. Benchmarking the performance of building energy management using data envelopment analysis. Appl. Therm. Eng. 2009, 29, 3269-3273. [CrossRef]

31. Hu, X.; Liu, C. Slacks-based data envelopment analysis for eco-efficiency assessment in the Australian construction industry. Constr. Manag. Econ. 2017, 35, 693-706. [CrossRef]

32. Chen, Y.; Liu, B.; Shen, Y.; Wang, X. The energy efficiency of China's regional construction industry based on the three-stage DEA model and the DEA-DA model. KSCE. J. Civ. Eng. 2016, 20, 34-47. [CrossRef]

33. Duan, N.; Guo, J.P.; Xie, B.C. Is there a difference between the energy and $\mathrm{CO}_{2}$ emission performance for China's thermal power industry? A bootstrapped directional distance function approach. Appl. Energy 2016, 162, 1552-1563. [CrossRef]

34. Sözen, A.; Alp, I.; Özdemir, A. Assessment of operational and environmental performance of the thermal power plants in Turkey by using data envelopment analysis. Energy Policy 2010, 38, 6194-6203. [CrossRef]

35. Khoshnevisan, B.; Rafiee, S.; Omid, M.; Mousazadeh, H. Applying data envelopment analysis approach to improve energy efficiency and reduce GHG (greenhouse gas) emissions of wheat production. Energy 2013, 58, 588-593. [CrossRef]

36. Yang, Z.; Wang, D.; Du, T.; Zhang, A.; Zhou, Y. Total-Factor Energy Efficiency in China's Agricultural Sector: Trends, Disparities and Potentials. Energies 2018, 11, 853. [CrossRef]

37. Hosseinzadeh-Bandbafha, H.; Safarzadeh, D.; Ahmadi, E.; Nabavi-Pelesaraei, A.; Hosseinzadeh-Bandbafha, E. Applying data envelopment analysis to evaluation of energy efficiency and decreasing of greenhouse gas emissions of fattening farms. Energy 2017, 120, 652-662. [CrossRef]

38. Hosseinzadeh-Bandbafha, H.; Safarzadeh, D.; Ahmadi, E.; Nabavi-Pelesaraei, A. Optimization of energy consumption of dairy farms using data envelopment analysis-A case study: Qazvin city of Iran. J. Saudi Soc. Agric. Sci. 2018, 17, 217-228. [CrossRef]

39. Mohseni, P.; Borghei, A.M.; Khanali, M. Coupled life cycle assessment and data envelopment analysis for mitigation of environmental impacts and enhancement of energy efficiency in grape production. J. Clean. Prod. 2018, 197, 937-947. [CrossRef]

40. Paramesh, V.; Arunachalam, V.; Nikkhah, A.; Das, B.; Ghnimi, S. Optimization of energy consumption and environmental impacts of arecanut production through coupled data envelopment analysis and life cycle assessment. J. Clean. Prod. 2018, 203, 674-684. [CrossRef]

41. Vázquez-Rowe, I.; Iribarren, D.; Moreira, M.T.; Feijoo, G. Combined application of life cycle assessment and data envelopment analysis as a methodological approach for the assessment of fisheries. Int. J. Life Cycle Assess. 2010, 15, 272-283. [CrossRef]

42. Laso, J.; Vázquez-Rowe, I.; Margallo, M.; Irabien, A.; Aldaco, R. Revisiting the LCA+DEA method in fishing fleets. How should we be measuring efficiency? Mar. Pol. 2018, 91, 34-40. [CrossRef]

43. Masuda, K. Measuring eco-efficiency of wheat production in Japan: A combined application of life cycle assessment and data envelopment analysis. J. Clean. Prod. 2016, 373-381. [CrossRef]

44. Nabavi-Pelesaraei, A.; Rafiee, S.; Mohtasebi, S.S.; Hosseinzadeh-Bandbafha, H.; Chau, K. Energy consumption enhancement and environmental life cycle assessment in paddy production using optimization techniques. J. Clean. Prod. 2017, 162, 571-586. [CrossRef] 
45. Cecchini, L.; Venanzi, S.; Pierri, A.; Chiorri, M. Environmental efficiency analysis and estimation of $\mathrm{CO}_{2}$ abatement cost in dairy cattle farms in Umbria (Italy): A SBM-DEA model with undesirable output. J. Clean. Prod. 2018, 197, 894-907. [CrossRef]

46. Iribarren, D.; Hospido, A.; Moreira, M.T.; Feijoo, G. Benchmarking environmental and operational parameters through eco-efficiency criteria for dairy farms. Sci. Total Environ. 2011, 409, 1786-1798. [CrossRef] [PubMed]

47. Margallo, M.; Onandía, R.; Aldaco, R.; Irabien, A. When life cycle thinking is necessary for decision making: Emerging cleaner technologies in the chlor-alkali industry. Chem. Eng. Trans. 2016, 52, 475-480.

48. ISO 14040: Environmental Management_Life Cycle Assessment_Principles and Framework; International Organization for Standardization: London, UK, 2006.

49. ISO 14044: Environmental Management_Life Cycle Assessment_Requirements and Guidelines; International Organization for Standardization: London, UK, 2006.

50. Rebitzer, G.; Ekvall, T.; Frischknecht, R.; Hunkeler, D.; Norris, G.; Rydberg, T.; Schmidt, W.P.; Suh, S.; Weidema, B.P.; Pennington, D.W. Life cycle assessment-Part 1: Framework, goal and scope definition, inventory analysis, and applications. Environ. Int. 2004, 30, 701-720. [CrossRef] [PubMed]

51. Guinée, J.B.; Udo de Haes, H.A.; Huppes, G. Quantitative life cycle assessment of products. 1: Goal definition and inventory. J. Clean. Prod. 1993, 1, 3-13. [CrossRef]

52. Margallo, M.; Dominguez-Ramos, A.; Aldaco, R.; Bala, A.; Fullana, P.; Irabien, A. Environmental sustainability assessment in the process industry: A case study of waste-to-energy plants in Spain. Resour. Conserv. Recycl. 2014, 93, 144-155. [CrossRef]

53. PE International. Gabi 6 Software and Database on Life Cycle Assessment; PE International: Leinfelden-Echterdingen, Germany, 2014.

54. Gustavsson, J.; Cederberg, C.; Sonesson, U.; Emanuelsson, A. The Methodology of the FAO Study "Global Food Losses and Food Waste_Extent, Causes and Prevention"; FAO, The Swedish Institute for Food and Biotechnology (SIK): Göteborg, Sweden, 2013.

55. Brand-Correa, L.; Brockway, P.; Copeland, C.; Foxon, T.; Owen, A.; Taylor, P. Developing an Input-Output Based Method to Estimate a National-Level Energy Return on Investment (EROI). Energies 2017, 10, 534. [CrossRef]

56. Hall, C.A.S.; Kiltgaard, K.A. Energy and the Wealth of Nations. Understanding the Biophysical Economy; Springer: New York, NY, USA, 2012.

57. Charnes, A.; Cooper, W.W.; Rhodes, E. Measuring the efficiency of decision making units. Eur. J. Oper. Res. 1978, 2, 429-444. [CrossRef]

58. Banker, R.D.; Charnes, A.; Cooper, W.W. Some models for estimating technical and scale inefficiencies in data envelopment analysis. Manag. Sci. 1984, 30, 1078-1092. [CrossRef]

59. Chu, J.; Wu, J.; Song, M. An SBM-DEA model with parallel computing design for environmental efficiency evaluation in the big data context: A transportation system application. Ann. Oper. Res. 2018, 270, 105-124. [CrossRef]

60. Iribarren, D.; Vázquez-Rowe, I.; Moreira, M.T.; Feijoo, G. Further potentials in the joint implementation of life cycle assessment and data envelopment analysis. Sci. Total Environ. 2010, 408, 5265-5272. [CrossRef] [PubMed]

61. Avadí, A.; Vázquez-Rowe, I.; Fréon, P. Eco-efficiency assessment of the Peruvian anchoveta steel and wooden fleets using LCA + DEA framework. J. Clean. Prod. 2014, 70, 118-131. [CrossRef]

62. Carrillo-Álvarez, E.; Pintó-Domingo, G.; Cussó-Parcerisas, I.; Riera-Romani, J. The Spanish Healthy Food Basket Complete Report. Pilot Project for the Development of a Common Methodology on Reference Budgets in Europe; Grup de Recerca en Pedagogia, Societat i Innovació amb el suport de les TIC (PSITIC): Barcelona, Spain, 2016.

63. MAPAMA, Spanish Ministry of Agriculture, Fishery, Food and Environment. Household Consumption Database. 2017. Available online: www.mapama.gob.es/es/alimentacion/temas/consumo-ycomercializacion-ydistribucion-alimentaria/panel-de-consumo-alimentario/base-de-datos-de-consumoen-hogares/ (accessed on 19 September 2018). (In Spanish)

64. Batlle-Bayer, L.; Bala, A.; García-Herrero, I.; Lemaire, E.; Song, G.; Aldaco, R.; Fullana, P. National Dietary Guidelines: A potential tool to reduce greenhouse gas emissions of current dietary patterns. The case of Spain. J. Clean. Prod.. Under review.

65. Eurostat. Fishery Production in All Fishing Regions (tag00117). 2015. Available online: http:/ / ec.europa.eu/ eurostat/data/database (accessed on 19 September 2018). 
66. Eurostat. Production and Utilization of Milk on the Farm_Annual Data (apro_mk_farm). 2015. Available online: http:/ / ec.europa.eu/eurostat/web/agriculture/data/database (accessed on 19 September 2018).

67. Eurostat. Slaughtering in Slaughterhouses-Annual Data (apro_mt_pann). 2015. Available online: http:/ / ec.europa.eu/eurostat/web/agriculture/data/database (accessed on 19 September 2018).

68. Eurostat. Crop Products—Annual Data (apro_cpp_crop). 2015. Available online: https://ec.europa.eu/ eurostat/web/agriculture/data / database (accessed on 19 September 2018).

69. Datacomex. Estadísticas del comercio exterior español, Agencia Española de Administración Tributaria. 2008. Available online: http:/ / datacomex.comercio.es / (accessed on 19 September 2018).

70. Milà i Canals, L.; Munoz, I.; Mclaren, S.J.; Brandão, M. LCA Methodology and Modelling Considerations for Vegetable Production and Consumption; Centre for Environmental Strategy, University of Surrey: Surrey, UK, 2007.

71. Nielsen, P.H.; Nielsen, A.M.; Weidema, B.P.; Dalgaard, R.; Halberg, N. LCA Food Database. 2003. Available online: http: / / www.lcafood.dk/ (accessed on 24 September 2018).

72. Foster, C.; Green, K.; Bleda, M.; Dewick, P.; Evans, B.; Flynn, M.J. Production and consumption: A research report completed for the department for environment. In Food and Rural Affairs by Manchester Business School; DEFRA: London, UK, 2006.

73. Farran, A.; Zamora, R.; Cervera, P. Nutrition and Dietetics Institute. In Food Composition Tables from CESNID; Barcelona University: Barcelona, Spain, 2004.

74. FAO-INFOODS. International Network of Food Data Systems. 2018. Available online: http://www.fao.org/ infoods/infoods/tablas-y-bases-de-datos/es / (accessed on 24 September 2018).

75. Jahanshahloo, G.R.; Hosseinzadeh, F.; Shoja, N.; Tohidi, G.; Razavyan, S. Undesirable inputs and outputs in DEA models. Appl. Math. Comp. 2005, 169, 917-925. [CrossRef]

76. Monforti-Ferrario, R.; Pinedo Pascua, I. Energy Use in the EU Food Sector: State of Play and Opportunities for Improvement; JRC Science and Policy Report; European Commission: Brussels, Belgium, 2015, ISBN 978-92-79-48299-1.

77. DEA Frontier. Joe Zhu's Research on Data Envelopment Analysis. 2018. Available online: http://www. deafrontier.net/index.html (accessed on 4 October 2018).

78. Murillo-Zamorano, L.R. Economic efficiency and frontier techniques. J. Econ. Surv. 2004, 18, 33-78. [CrossRef]

79. Ghasempour, A.; Ebrahim, A. Assessment of the environment impacts of egg production chain using life cycle assessment. J. Environ. Manag. 2016, 183, 980-987. [CrossRef]

80. Avadí, A.; Fréon, P.; Quispe, I. Environmental assessment of Peruvian anchoveta food production: Is less refined better? Int. J. Life Cycle Assess. 2014, 19, 1276-1293. [CrossRef]

81. Avadí, A.; Bolaños, C.; Sandoval, I.; Ycaza, C. Life cycle assessment of Ecuadorian processed tuna. Int. J. Life Cycle Assess. 2015, 20, 1415-1428. [CrossRef]

82. Vázquez-Rowe, I.; Villanueva-Rey, P.; Hospido, A.; Moreira, M.T.; Feijoo, G. Life cycle assessment of European pilchard (Sardina pilchardus) consumption. A case study for Galicia (NW Spain). Sci. Total Environ. 2014, 475, 48-60. [CrossRef]

(C) 2018 by the authors. Licensee MDPI, Basel, Switzerland. This article is an open access article distributed under the terms and conditions of the Creative Commons Attribution (CC BY) license (http://creativecommons.org/licenses/by/4.0/). 